\title{
Impact of cash flow volatility and debt structure in context of COVID pandemic: A study in Vietnam
}

\author{
Nguyen Thi Xuan HONG ${ }^{1}$, Dang Ngoc HUNG ${ }^{*}$ \\ ${ }^{1}$ Ph.Dr Hanoi University of Industry, Vietnam; E-mail: nguyenthixuanhong@haui.edu.vn \\ 2Professor, Ph.Dr, Hanoi University of Industry, Vietnam; E-mail: dangngochung@haui.edu.vn \\ * Corresponding Author
}

\author{
Received: 09.11.2021 Accepted: 11.12.2021 Published: 02.02.2022 $\quad$ DOI: 10.47750/QAS/23.186.34
}

\begin{abstract}
The study examines the impact of cash flow volatility on the debt structure of listed enterprises in Vietnam in period from 2009 to 2020. We use general least square method and percentile regression to examine this impact. Research results show that there exists an inverse relationship between cash flow volatility and corporate debt structure (financial leverage, short-term debt and long-term debt) of Vietnamese enterprises during the research period. In particular, unlike previous studies on cash flow volatility, this study further examines impact of the COVID pandemic on the relationship between cash flow volatility and debt structure. The test results show that cash flow volatility in the context of the COVID-19 pandemic has an positive impact on debt structure. At the same time, the study also finds that the cash flow volatility will decrease as the percentile of the debt structure increases.
\end{abstract}

Keyword: Cash flow volatility; Debt structure; Short-term debt; Long-term debt; Percentile regression; COVID

\section{Introduction}

Financing decision is one of the important financial decisions of enterprises. In fact, when making financing decisions for establishing an optimal capital structure, enterprises need to be careful when choosing between debt and equity. There are each different advantages and disadvantages in using each source of capital due to its own characteristics. Choosing debt as the source of financing has the advantage of low capital cost and the leverage impact of debt that amplifies earnings for owners, but provided that the enterprise is profitable and able to pay interest on loans. But the disadvantage of using debt is the exposure to financial risks, which will create instability in the owner's income, and, importantly, can make enterprises face financial distress and bankruptcy risks. Whereas if the source of funding used is equity, then companies do not face financial risk because shareholders will share the risk with the company and it is easier to raise capital. However, using equity has the disadvantage of not having financial leverage to amplify income for owners and it is also a source of financing that has higher capital cost than debt. Therefore, it is extremely important to be able to build an optimal capital structure for each enterprise to maximize income for owners, minimize capital costs and risks, and promote business development. Not only enterprises but many scientists around the world are interested in the planning and establishment of an optimal capital structure Up to this point, a lot of topics related to capital structure have been studied and implemented, in which the most prominent are studies on factors affecting the level of debt used in capital structure such as: studies by Myers \& Majluf (1984), Wald (1999), Chen (2004), Frank \& Goyal (2009). However, most of these studies only focus on and provide evidences that factors such as market value to book value, fixed assets, profitability, firm size affect the level of debt used in the capital structure. Meanwhile, cash flow volatility is also a factor affecting the level of debt used in the capital structure of enterprises but has been studied less often. There are evidences that fluctuations in cash flow affect the use of debt as studied by Bates et al. (2009), Memon et al. (2018), Harris \& Roark (2019).

In the context that Vietnam's economy is gradually integrating with the world economy, it is very important to help Vietnamese enterprises have more insight in considering cash flow volatility before deciding the optimal capital structure so that they can make full use of capital resources. Besides, this study also provides empirical results on how cash flow volatility in the context of the COVID pandemic will affect the debt structure of enterprises.

\section{Theoretical framework}

The trade-off theory of capital structure states that the optimal capital structure of an enterprise is determined by the trade-off between the benefits of debt - the benefit from the tax shield and the cost of borrowing - financial distress costs. The more debt an enterprise uses, the greater the benefit of the tax shield, but the cost of financial distress also increases. Therefore, creditors will also require a higher rate of return, increasing the company's cost of capital. Therefore, the optimal capital structure of an enterprise is determined by increasing the amount of debt until the marginal benefit from the tax shield equals the marginal cost of financial distress. According to the capital structure trade-off theory, several arguments are used to explain why enterprises try to adjust their capital structure to a certain appropriate debt ratio. In other words, enterprises have different target debt ratios because of the constraints on debt contracts, the possibility of business bankruptcy, the reputation of the directors, the ratio of fixed assets, etc. tangibles and profitability of the business.

The pecking order theory was initially studied by Myers \& 


\section{GENERAL MANAGEMENT}

Majluf (1984). This theory states that there is no optimal financial leverage because at this time, equity capital exists in two forms: internal equity from retained earnings and equity from new issuance. This theory focuses on studying the priority order of funding sources used by enterprises to meet the capital needs for investment activities. Internal funding is prioritized to be used first. If retained earnings are not enough, and external funding needs to be mobilized, debt will be given priority. The source of equity capital from new issuance comes last. When an enterprise uses debt to finance, it faces fixed interest costs that it has to pay its creditors. In return, however, it is better to issue debt due to the benefit of the tax shield of the interest cost. However, interest cost is always considered as a fixed financial expense. No matter how the operating results are, whether the enterprise's profit is a lot, a little, or even a loss, such enterprise is still required to pay interest to creditors, from which the use of debt increases financial risks for the company. Therefore, the cost of debt is lower than that of equity only if and when the enterprise is expected to do well, generate steady cash flow, thus enabling the enterprise to repay its debt and interest to its creditors on due term. Thus, information asymmetry affects the choice between internal or external financing, and between issuing debt or equity. Enterprise will issue shares only if the price of the shares is affordable or highly valued. The pecking order theory also explains why profitable firms borrow less, not because they have a low target debt ratio, but because they don't actually need external financing. Less profitable firms issue debt because internal financing - retained earnings - is insufficiently financed and debt ranks first in the pecking order of external financing.

\section{Literature review}

There have been many previous studies to verify the impact of cash flow volatility on the level of debt used in the capital structure of enterprises. There are outstanding studies such as those of Bates et al. (2009), Denis \& McKeon (2018), Huang \& Ritter (2021), Keefe \& Yaghoubi (2016), Memon et al. (2018). However, there have been conflicting trends in the correlation between cash flow volatility and the level of debt used in enterprises' capital structures.

When conducting research to understand why firms in the US hold more cash than they actually use Bates et al. (2009) presented evidence that depending on the business performance, existing financial position as well as the characteristics of each enterprise, the amount of cash held in each enterprise is different. In times of crisis, because of anxiety about the business future, when there is a high volatility in cash flow, enterprises tend to hold more cash. In other words, when cash flow volatility occurs, enterprises tend to hold cash to make up for the shortfall in operating cash flow, so that they do not need to use external financing.

Meanwhile, when studying debt financing and financial flexibility through increasing the level of financial leverage used in the capital structure of firms operating in the US with total assets greater than $\$ 10$ million between 1971 and 1999, Denis \& McKeon (2018) pointed out that enterprises increase financial leverage through debt issuance mainly to cover operating needs rather than pay dividends to shareholders. In other words, when enterprises' operating cash flows are in deficit, they will borrow more debt to make up for their shortfalls. In the study about the problem of cash deficit and financial decisions of enterprises, Huang \& Ritter (2021) asserted that, when enterprises face future cash flow shortages, they will tend to use external financing that is debt or new equity issue. Accordingly, when faced with a shortage of money, they will increase the use of debt rather than increase the use of newly issued equity. This makes sense because according to the pecking order theory, when internal financing are exhausted, enterprises will prefer debt. Only when debt financing does not meet the needs of enterprises, they will use equity financing from new issuance. When conducting research on the impact of cash flow volatility on the level of debt used in the capital structure of firms, Keefe \& Yaghoubi (2016) has shown that the higher the volatility of cash flows, the higher the firms" capital structure. They will tend to switch from using long-term debt to short-term debt with the main purpose of reducing borrowing costs.

Memon et al. (2018) showed a negative correlation between cash flow volatility and financial leverage of firms in China. As the majority of companies in China are controlled by the government, the impact of cash flow volatility on the level of debt used in the capital structure of firms is not large. It is because when fluctuations occur, with the government as the owner, banks feel secured when providing loans to firms. Memon et al. (2018) suggested that when cash flow volatility increases, enterprises will limit holding long-term debt. When enterprises are sorted by operating cash flow, will cash flow volatility have an impact on capital structure? When looking into this, Harris \& Roark (2019) found evidence that the relationship between capital structure and cash flow volatility is most relevant for firms with low operating cash flow, and the relationship weakens as operating cash flow increases.

\section{Research methods and models}

This study uses secondary data, with panel data collected from annual audited and published financial statements on the Vietnamese stock exchange. The research sample is collected from non-financial companies (All businesses, except financial, insurance, and banking businesses) with operating time from 2009 to 2020. This study uses the quantitative research and GLS (General Least Square) methods, which will overcome autocorrelation phenomenon. Also, variance and percentile regression are used to examine the impact of cash flow volatility on the level of debt used in Vietnamese listed enterprises. Based on the literature review and research objectives mentioned above, we build the model as follows:

Model 1: Structure Debti,t $=\beta 0+\beta 1$ VCFi,t $+\alpha 1$ SIZEi, $t+$ $\alpha 2 T A N G i, t+\alpha 3 R O A i, t+\alpha 3 M B i, t+\alpha 4 L I Q i, t+\varepsilon i, t(1)$

\begin{tabular}{|l|l|l|l|l|}
\hline Name of variable & $\begin{array}{l}\text { Type of } \\
\text { variable }\end{array}$ & $\begin{array}{l}\text { Variable } \\
\text { code }\end{array}$ & Measurement method & $\begin{array}{l}\text { Impact } \\
\text { direction }\end{array}$ \\
\hline Debt & Dependent & LVit & LVit = Debtit/Total assetsit & \\
\hline Short-term debt & Dependent & SDAit & SDAit = Short-termit /Total assetsit & \\
\hline Long-term debt & Dependent & LDAit & $\begin{array}{l}\text { LDAit = Long-term debt/ Total } \\
\text { assetsit }\end{array}$ & \\
\hline Cash flow volatility & Independent & VCFit & $\begin{array}{l}\text { VCFit }=\text { Standard Deviation(Free } \\
\text { Cash Flowit)/ Total assetsit }\end{array}$ & - \\
\hline Firm size & Control & SIZEit & SIZEit = Log (Total Assetsit) & $+/-$ \\
\hline
\end{tabular}




\section{GENERAL MANAGEMENT}

\begin{tabular}{|c|c|c|c|c|}
\hline Name of variable & $\begin{array}{l}\text { Type of } \\
\text { variable }\end{array}$ & $\begin{array}{l}\text { Variable } \\
\text { code }\end{array}$ & Measurement method & $\begin{array}{l}\text { Impact } \\
\text { direction }\end{array}$ \\
\hline Fixed assets & Control & TANGit & $\begin{array}{l}\text { TANGit = Fixed assets it } / \text { Total } \\
\text { assetsit }\end{array}$ & \\
\hline Profitability & Control & ROAit & $\begin{array}{l}\text { ROAit = Profit after tax it/ Total } \\
\text { assetsit }\end{array}$ & \\
\hline Market to book value & Control & MBit & $\begin{array}{l}\text { MBit = Market Value of Assetsit/ } \\
\text { Book Value of Assetsit }\end{array}$ & \\
\hline Liquidity & Control & LIQit & $\begin{array}{l}\text { LIQit = Current Assets / Current } \\
\text { Liabilitiesit }\end{array}$ & \\
\hline
\end{tabular}

Table 1: Summary of variables in the research model

Debt structure includes leverage ratios, short-term debt and long-term debt. We measure these indicators by the ratio between total debt, short-term debt, and long-term debt to total assets of the enterprises according to Frank \& Goyal (2009). The use of financial leverage will help amplify earnings for the owners of enterprises. However, the use of financial leverage will also expose enterprises to financial risk.

Volatility in cash flow (VCF): According to the results of a research paper by Harris \& Roark (2019), there is a positive correlation between cash flow volatility and the level of financial leverage in companies with low operating cash flow. However, the study of Memon et al. (2018) showed that, there is a negative correlation between cash flow volatility and the level of financial leverage. It is because when cash flow volatility occur, due to the fact that the majority of Chinese enterprises are owned by the government, they are only slightly affected by cash flow volatility, namely limited long-term debt and the debt ratio reduces. In this study, when examining Vietnamese enterprises, we expect the coefficient of cash flow volatility to be negative because they have more similarities with Chinese enterprises than those in the U.S. Inheriting the study of Bates et al. (2009), we measure cash flow volatility by using the standard deviation of cash flow divided by total assets Memon et al. (2018), Harris \& Roark (2019). The formula to calculate free cash flow according to Bates et al. (2009) is as follows:

Free cash flowit $=$ EBITit+ Depreciationit - Interestit - Taxit - Dividentit

$=$ Profit after taxit + Depeciationit - Dividentit

In addition to the dependent variables, and the cash flow volatility presented above, in the research model, we also consider a number of control variables that have been used in previous studies with statistical significance such as firm size, fixed assets, profitability, market value of assets, liquidity such as in $\mathrm{Ha}$ et al (2019), Phuong et al. (2020), Van Khanh \& Hung (2020), Dang \& Tran (2020). The variables in the research model are briefly described in Table 1.

The COVID pandemic is one of the reasons why profits from production and business activities in enterprises become unstable. Enterprises, especially those that are financially constrained, are more likely to face shocks in cash flow, which in turn forces this group of enterprises to approach other sources of funding to offset the shortfall as well as to finance investment decisions. In Vietnam and in the world, a series of enterprises have been heavily affected by the COVID-19 pandemic since the end of 2019 until now. In this period, many enterprises face difficulties in their production and business activities, so retained earnings from operating cash flows may not be sufficient to finance investment decisions. They have to resort to mobilizing additional external funding sources. This impact is expected to be more pronounced for financially constrained enterprises which are facing shocks from the impact of the pandemic. At the same time, the COVID-19 pandemic is assessed as an event with a risk of transmission. (Baker et al., 2020) states that no previous infectious disease, including the Spanish flu, has affected the stock market as strongly as the COVID-19 pandemic. Yan et al. (2020), analyzes the potential impact of COVID-19 on the stock market, and suggest possible ways an individual can profit from the market affected by the global virus outbreak. The authors look at past outbreaks and come to the conclusion that markets will often react adversely to such incidents in the short term but in the long run, markets eventually correct themselves and rise up. On that basis, the authors suggest buying and selling stocks in industries that will be immediately affected by the virus in a short time. Besides the impact of the COVID pandemic on business performance (Dang et al., 2021), the cash flow of enterprises will be affected, which will lead to significant decrease in capital funding. Therefore, we develop the next 2 hypotheses.

Model 2: Structure Debti, $\mathrm{t}=\beta 0+\beta 1 \mathrm{VCFi}, \mathrm{t}+$ B2VCF_COVIDi,t $+\alpha 1$ SIZEi,t+ $\alpha 2$ TANG i,t $+\alpha 3 R O A i, t+\alpha 3 M B$ $\mathrm{i}, \mathrm{t}+\alpha 4 \overline{\mathrm{L}} \mathrm{QQ} \mathrm{i}, \mathrm{t}+\varepsilon \mathrm{\varepsilon i}, \mathrm{t}(1)$

In which: COVIDit is a dummy variable for data in 2020 , which is the year of the impact of the COVID pandemic; the variable VCF_COVIDit is an interaction variable between the COVID pandemic and cash flow volatility (VCF).

\section{Results and discussion}

Table 2 shows the results of descriptive statistics for the variables used in the regression analysis, including: Financial leverage (LV), short-term debt ratio (SDA, long-term financial debt ratio (LDA), volatility of cash flow (VCF), company size (SIZE), tangible fixed assets (TANG), profitability (ROA), market value/book value (MB), profitability liquidity (LIQ) The results show that on average, enterprises in the sample using financial leverage, short-term debt to total assets, and longterm debt account for $49.1 \%, 39.5 \%$, and $9.7 \%$, respectively. The average cash flow volatility is $2.9 \%$ per year.

\begin{tabular}{|l|l|l|l|l|l|}
\hline Variable & Obs & Mean & Std. Dev. & Min & Max \\
\hline LV & 5,887 & 0.491 & 0.222 & 0.002 & 2.031 \\
\hline SDA & 5,887 & 0.394 & 0.210 & 0.002 & 1.991 \\
\hline LDA & 5,887 & 0.097 & 0.137 & -0.004 & 0.787 \\
\hline VCF & 5,887 & 0.029 & 0.092 & 0.000 & 4.628 \\
\hline SIZE & 5,887 & 27.148 & 1.533 & 23.330 & 33.677 \\
\hline TANG & 5,887 & 0.197 & 0.198 & 0.000 & 0.978 \\
\hline ROA & 5,887 & 0.060 & 0.087 & -1.779 & 0.784 \\
\hline
\end{tabular}




\section{GENERAL MANAGEMENT}

\begin{tabular}{|l|l|l|l|l|l|}
\hline MB & 5,887 & 0.980 & 1.227 & 0.082 & 72.101 \\
\hline LIQ & 5,887 & 2.390 & 4.695 & 0.058 & 229.779 \\
\hline
\end{tabular}

Table 2: Descriptive Statistics

Table 3 presents more details about the debt structure of enterprises in Vietnam, at the $25 \%, 50 \%$ and $75 \%$ percentiles. For financial leverage, at the $25 \%, 50 \%$, and $75 \%$ percentiles, the average debt ratio is $31.7 \%, 51.2 \%$, and $66.5 \%$; while short-term debt is $22.3 \%, 38.1 \%, 55.2 \%$ respectively; The ratio of long-term debt of enterprises is low compared to the total assets of enterprises, corresponding to the percentiles of $0.3 \%$, $3.3 \%$ and $14.5 \%$, respectively.

Table 4 shows the correlation coefficient matrix among the variables used in the research model. Cash flow volatility is negatively correlated with financial leverage, short-term debt, and long-term debt; it is statistically significant. Meanwhile, the relationship between debt structure and internal factors in enterprises is negatively correlated with market price index, profitability, fixed assets, liquidity; it is only positively correlated to firm size. In general, the degree of correlation among the variables in the model is relatively low, and multicollinearity rarely happens.

\begin{tabular}{|l|l|l|l|l|l|l|l|l|l|}
\hline \multirow{2}{*}{ year } & LV & \multicolumn{1}{l}{ SDA } & LDA & Q75 \\
\cline { 2 - 9 } & Q25 & Q50 & Q75 & Q25 & Q50 & Q75 & Q25 & Q50 & Q7 \\
\hline 2009 & $33.8 \%$ & $52.7 \%$ & $66.9 \%$ & $24.0 \%$ & $39.3 \%$ & $52.6 \%$ & $0.7 \%$ & $4.3 \%$ & $16.4 \%$ \\
\hline 2010 & $33.5 \%$ & $53.7 \%$ & $66.0 \%$ & $23.4 \%$ & $38.8 \%$ & $54.3 \%$ & $0.7 \%$ & $4.3 \%$ & $17.0 \%$ \\
\hline 2011 & $34.9 \%$ & $54.3 \%$ & $67.6 \%$ & $25.2 \%$ & $40.2 \%$ & $56.2 \%$ & $0.6 \%$ & $4.3 \%$ & $15.5 \%$ \\
\hline 2012 & $34.0 \%$ & $54.4 \%$ & $67.3 \%$ & $25.4 \%$ & $40.7 \%$ & $57.0 \%$ & $0.1 \%$ & $3.0 \%$ & $15.6 \%$ \\
\hline 2013 & $33.9 \%$ & $53.0 \%$ & $68.1 \%$ & $24.6 \%$ & $40.3 \%$ & $56.9 \%$ & $0.1 \%$ & $3.5 \%$ & $14.3 \%$ \\
\hline 2014 & $30.9 \%$ & $50.8 \%$ & $66.7 \%$ & $21.5 \%$ & $37.9 \%$ & $56.9 \%$ & $0.1 \%$ & $2.6 \%$ & $14.3 \%$ \\
\hline 2015 & $30.1 \%$ & $49.3 \%$ & $66.4 \%$ & $21.0 \%$ & $35.7 \%$ & $55.9 \%$ & $0.2 \%$ & $3.4 \%$ & $14.1 \%$ \\
\hline 2016 & $29.0 \%$ & $49.0 \%$ & $65.8 \%$ & $19.9 \%$ & $35.2 \%$ & $53.7 \%$ & $0.2 \%$ & $3.0 \%$ & $14.2 \%$ \\
\hline 2017 & $31.1 \%$ & $51.1 \%$ & $65.7 \%$ & $21.1 \%$ & $38.7 \%$ & $55.5 \%$ & $0.2 \%$ & $3.2 \%$ & $14.5 \%$ \\
\hline 2018 & $31.4 \%$ & $50.2 \%$ & $65.5 \%$ & $21.9 \%$ & $38.2 \%$ & $55.3 \%$ & $0.2 \%$ & $2.9 \%$ & $13.1 \%$ \\
\hline 2019 & $31.7 \%$ & $48.8 \%$ & $65.0 \%$ & $22.1 \%$ & $37.3 \%$ & $54.7 \%$ & $0.3 \%$ & $2.9 \%$ & $12.0 \%$ \\
\hline 2020 & $29.0 \%$ & $45.4 \%$ & $63.1 \%$ & $18.4 \%$ & $33.0 \%$ & $49.1 \%$ & $0.2 \%$ & $3.1 \%$ & $15.2 \%$ \\
\hline Total & $31.7 \%$ & $51.2 \%$ & $66.5 \%$ & $22.3 \%$ & $38.1 \%$ & $55.2 \%$ & $0.3 \%$ & $3.3 \%$ & $14.5 \%$ \\
\hline
\end{tabular}

Table 3: Descriptive statistics of each year's debt structure variables by percentile

\begin{tabular}{|l|l|l|l|l|l|l|l|l|l|}
\hline & LV & SDA & LDA & VCF & SIZE & TANG & ROA & MB & LIQ \\
\hline LV & 1 & & & & & & & & \\
\hline SDA & $0.8014^{*}$ & 1 & & & & & & & \\
\hline LDA & $0.3905^{*}$ & $-0.2376^{*}$ & 1 & & & & & & \\
\hline VCF & $-0.0738^{*}$ & $-0.0522^{*}$ & $-0.0394^{*}$ & 1 & & & & & \\
\hline SIZE & $0.3126^{*}$ & $0.0853^{*}$ & $0.3764^{*}$ & $-0.0842^{*}$ & 1 & & & & \\
\hline TANG & $-0.0313^{*}$ & $-0.2444^{*}$ & $0.3253^{*}$ & $0.0316^{*}$ & $0.0288^{*}$ & 1 & & & \\
\hline ROA & $-0.3648^{*}$ & $-0.2781^{*}$ & $-0.1644^{*}$ & $-0.1205^{*}$ & -0.023 & $0.0455^{*}$ & 1 & & \\
\hline MB & $-0.0498^{*}$ & $-0.0379^{*}$ & -0.023 & $0.3114^{*}$ & $0.0278^{*}$ & 0.0243 & $0.1250^{*}$ & 1 & \\
\hline LIQ & $-0.3636^{*}$ & $-0.3332^{*}$ & $-0.0778^{*}$ & $0.0469^{*}$ & $-0.1148^{*}$ & $-0.0886^{*}$ & $0.0873^{*}$ & $0.0525^{*}$ & 1 \\
\hline
\end{tabular}

Table 4: Correlation Matrix

t statistics in brackets * $p<0.05$

Table 5 shows the results of the regression coefficients of the independent and control variables for the dependent variable of financial leverage, short-term debt and long-term debt - representing the debt structure in the capital structure of companies. The estimated results show that the overall cash flow volatility has a negative impact on the level of debt use and is statistically significant. Meanwhile, the control variables in the research model all affect the debt structure of the enterprise.

\begin{tabular}{|l|l|l|l|}
\hline & LV & SDA & LDA \\
\hline VCF & $-0.208^{\star * *}$ & $-0.151^{* * *}$ & $-0.0572^{\star * *}$ \\
\hline & {$[-7.53]$} & {$[-5.45]$} & {$[-3.24]$} \\
\hline SIZE & $0.0380^{* * *}$ & $0.00588^{* * *}$ & $0.0322^{* * *}$ \\
\hline & {$[24.26]$} & {$[3.75]$} & {$[32.06]$} \\
\hline TANG & $-0.0541^{* * *}$ & $-0.279^{* * *}$ & $0.225^{\star * *}$ \\
\hline & {$[-4.48]$} & {$[-23.06]$} & {$[29.04]$} \\
\hline
\end{tabular}




\section{GENERAL MANAGEMENT}

\begin{tabular}{|c|c|c|c|}
\hline $\mathrm{ROA}$ & $-0.877^{\star \star \star *}$ & $-0.602^{\star \star \star}$ & $-0.276^{* * *}$ \\
\hline & {$[-31.24]$} & [-21.42] & {$[-15.34]$} \\
\hline \multirow[t]{2}{*}{ MB } & $0.00544^{\star \star *}$ & $0.00622^{\star * *}$ & -0.000784 \\
\hline & [2.62] & {$[3.00]$} & {$[-0.59]$} \\
\hline \multirow[t]{2}{*}{ LIQ } & $-0.0144^{\star \star *}$ & $-0.0147^{* * *}$ & 0.000291 \\
\hline & {$[-28.05]$} & {$[-28.61]$} & {$[0.89]$} \\
\hline \multirow[t]{2}{*}{ cons } & $-0.443^{* * *}$ & $0.359^{\star * *}$ & $-0.802^{* * *}$ \\
\hline & {$[-10.34]$} & [8.37] & {$[-29.25]$} \\
\hline $\mathrm{N}$ & 5887 & 5887 & 5887 \\
\hline
\end{tabular}

Table 5: Regression results of the model

Firstly, we find a negative correlation between cash flow volatility and financial leverage of enterprises. This result is shown through the regression coefficient of the variable VCF which is -0.208 and has statistical significance at $1 \%$. At the same time, cash flow volatility also has a negative impact on the short-term debt ratio (SDA) and long-term debt ratio (LDA) and is statistically significant, in which the impact of short-term debt is larger than that of long-term debt, with the coefficients of -0.151 and -0.0572 , respectively. This implies that, when enterprises have high cash flow volatility, they tend to reduce the level of debt used in capital structure. This result is consistent with the study of Memon et al. (2018). It is probably because enterprises with high cash flow volatility have high business risks which increase the probability of financial distress and reduce the present value of the tax shield (Jensen, 1986). Therefore, these enterprises often reduce debt to reduce the financial risk affecting the overall risk of the business.

Besides, we find a positive correlation between firm size (SIZE) variable representing firm size and debt structure and is statistically significant at the $1 \%$ level. This means that larger enterprises will use more debt in their capital structure. Largescale enterprises are often reputable companies in the market. Moreover, information asymmetry in these enterprises is often less severe than in small-sized enterprises, so it will It is easier to create credibility with banks and they can easily access loans with lower cost of capital. For the variable fixed assets (TANG), there is a negative correlation between tangible assets and the debt structure of the business, which is statistically significant. This research result is in contrast to the research results of Harris \& Roark (2019), because the authors believe that enterprises with many tangible assets will reduce their losses if they go bankrupt. Besides, tangible assets can be seen as reliable collateral for creditors. Therefore, for enterprises with a larger ratio of tangible assets to total assets, their capital structure will tend to use more financial leverage. However, the fact that an enterprise holds a large amount of tangible assets also implies that it has stable profits, and large internal capital and is not encouraged to use external financing. This is consistent with the pecking order theory and the negative correlation between profitability and financial leverage that the authors found in this study. Next, we find a negative correlation between profitability (ROA) and corporate debt structure. This result is consistent with the pecking order theory. For enterprises with high profitability and abundant internal funds, when needing to finance projects, enterprises will choose internal capital sources first. As a result, external funding sources will decrease and enterprises borrow less.

\begin{tabular}{|l|l|l|l|}
\hline & LV & SDA & LDA \\
\hline VCF & $-0.529^{* * *}$ & $-0.375^{* * *}$ & $-0.155^{\star * *}$ \\
\hline & {$[-10.60]$} & {$[-7.48]$} & {$[-4.82]$} \\
\hline VCF_COVID & $0.444^{* * *}$ & $0.310^{* * *}$ & $0.135^{* * *}$ \\
\hline & {$[7.71]$} & {$[5.36]$} & {$[3.64]$} \\
\hline SIZE & $0.0376^{* * *}$ & $0.00558^{* * *}$ & $0.0320^{* * *}$ \\
\hline & {$[24.08]$} & {$[3.56]$} & {$[31.94]$} \\
\hline TANG & $-0.0509^{* * *}$ & $-0.276^{* * *}$ & $0.226^{* * *}$ \\
\hline & {$[-4.23]$} & {$[-22.91]$} & {$[29.18]$} \\
\hline ROA & $-0.908^{* * *}$ & $-0.623^{* * *}$ & $-0.285^{* * *}$ \\
\hline & {$[-32.17]$} & {$[-22.02]$} & {$[-15.72]$} \\
\hline MB & 0.00298 & $0.00451^{* *}$ & -0.00153 \\
\hline & {$[1.43]$} & {$[2.15]$} & {$[-1.14]$} \\
\hline LIQ & $-0.0142^{* * *}$ & $-0.0146^{* * *}$ & 0.000345 \\
\hline & {$[-27.81]$} & {$[-28.41]$} & {$[1.05]$} \\
\hline Cons & $-0.421^{* * *}$ & $0.375^{* * *}$ & $-0.796^{* * *}$ \\
\hline & {$[-9.85]$} & {$[8.74]$} & {$[-28.97]$} \\
\hline N & 5887 & 5887 & 5887 \\
\hline
\end{tabular}

Table 6: Regression results of model 2 about the impact of COVID t statistics in brackets ${ }^{*} p<0.1,{ }^{* *} p<0.05,{ }^{* * *} p<0.01$

Table 6 presents the results of the second model analyzing the impact of cash flow volatility on debt structure for listed enterprises in Vietnam during the COVID pandemic. It can be seen that the correlation coefficient of the variable "cash flow volatility" (VCF) with debt structure has a negative relationship and is statistically significant at $1 \%$. When considering the 


\section{GENERAL MANAGEMENT}

impact of the COVID pandemic, with the interaction variable VCF COVID on the level of debt use, the results show a positive relationship and the $1 \%$ significance level. Thus, the COVID pandemic affects cash flow volatility and thereby greatly affect the debt structure of enterprises.

For a comprehensive review, we perform quantile regression $n$ at the Q25\%, Q50\% and Q75\% percentiles. Table 7 presents the quartile regression results which show that cash flow volatility is negatively related to financial leverage; the lower the percentile level (the lower the financial leverage ratio), the the greater the impact of cash flow fluctuations. The relation between debt structure for the short-term debt ratio is also similar. The cash flow volatility is also negatively related and statistically significant according to the decreasing impact level when the short-term debt ratio in different percentiles increases. Besides, the cash flow volatility only have negative impact with statistical significance at the Q25\% percentile and without statistical significance at Q50\% and Q75\% percentiles.

In Table 8, when considering the impact of the COVID pandemic, the interaction variable VCF COVID has a positive relationship with statistical significance; it decreases as the percentiles increases. Meanwhile, for the short-term debt ratio, the cash flow volatility when interacting with the COVID pandemic variable only have impact at the Q25\% and Q50\% percentiles, and not at the Q75\% percentile. In contrast to the long-term debt ratio, the interaction variable has no impact at different percentiles.

\begin{tabular}{|c|c|c|c|c|c|c|c|c|c|}
\hline & \multicolumn{3}{|l|}{ LV } & \multicolumn{3}{|l|}{ SDA } & \multicolumn{3}{|l|}{ LDA } \\
\hline & Q25 & Q50 & Q75 & Q25 & Q50 & Q75 & Q25 & Q50 & Q75 \\
\hline \multirow[t]{2}{*}{ VCF } & $-0.231^{* * *}$ & $-0.144^{* * *}$ & $-0.117^{\text {***}}$ & $-0.126^{* * *}$ & $-0.125^{\star * *}$ & $-0.0738^{*}$ & $-0.0154^{*}$ & -0.00647 & -0.0221 \\
\hline & {$[-6.52]$} & {$[-3.92]$} & {$[-3.49]$} & {$[-4.96]$} & {$[-3.26]$} & {$[-1.73]$} & {$[-1.75]$} & {$[-0.38]$} & {$[-0.64]$} \\
\hline \multirow[t]{2}{*}{ SIZE } & $0.0284^{\star * \star}$ & $0.0299^{* * *}$ & $0.0285^{\star \star \star}$ & $-0.00701^{* * *}$ & -0.0021 & 0.000229 & $0.00740^{\star \star *}$ & $0.0212^{\star \star *}$ & $0.0374^{\star \star *}$ \\
\hline & [14.16] & [14.32] & [14.98] & {$[-4.85]$} & {$[-0.96]$} & {$[0.09]$} & [14.82] & [22.12] & [18.96] \\
\hline \multirow[t]{2}{*}{ TANG } & $-0.148^{\star \star *}$ & $-0.114^{\star \star \star}$ & $-0.123^{\star \star \star}$ & $-0.291^{* * *}$ & $-0.375^{\star * *}$ & $-0.434^{\star \star \star}$ & $0.0628^{\star * *}$ & $0.208^{\star \star \star}$ & $0.287^{\star \star *}$ \\
\hline & {$[-9.53]$} & {$[-7.09]$} & {$[-8.39]$} & {$[-26.17]$} & {$[-22.34]$} & {$[-23.27]$} & [16.30] & [28.15] & [18.89] \\
\hline \multirow[t]{2}{*}{$\mathrm{ROA}$} & $-0.501^{* \star *}$ & $-0.983^{* * *}$ & $-1.301^{* * *}$ & $-0.0694^{* * *}$ & $-0.478^{* * *}$ & $-0.907^{\star * *}$ & $-0.0440^{* * *}$ & $-0.135^{\star * *}$ & $-0.297^{* * *}$ \\
\hline & {$[-13.94]$} & {$[-26.28]$} & {$[-38.19]$} & {$[-2.69]$} & {$[-12.28]$} & {$[-20.96]$} & {$[-4.92]$} & {$[-7.87]$} & {$[-8.41]$} \\
\hline \multirow[t]{2}{*}{$\mathrm{MB}$} & 0.00421 & $0.0143^{* * *}$ & $0.0204^{* * *}$ & $0.00734^{* * *}$ & $0.0195^{\star * *}$ & $0.0255^{* * *}$ & $-0.00192^{* * *}$ & $-0.00273^{\star *}$ & 0.000993 \\
\hline & [1.58] & [5.20] & [8.10] & [3.85] & {$[6.80]$} & [7.99] & {$[-2.91]$} & {$[-2.15]$} & {$[0.38]$} \\
\hline \multirow[t]{2}{*}{ LIQ } & $-0.0678^{* * *}$ & $-0.0494^{\star * *}$ & $-0.0294^{* * *}$ & $-0.0574^{\star \star *}$ & $-0.0572^{\star * *}$ & $-0.0352^{\star \star \star}$ & -0.000255 & -0.000166 & 0.000375 \\
\hline & {$[-102.97]$} & {$[-72.19]$} & {$[-47.14]$} & {$[-121.39]$} & {$[-80.23]$} & [-44.49] & {$[-1.56]$} & {$[-0.53]$} & {$[0.58]$} \\
\hline \multirow[t]{2}{*}{ cons } & $-0.180^{* * *}$ & $-0.136^{\star *}$ & -0.00422 & $0.657^{\star * *}$ & $0.654^{\star \star \star *}$ & $0.709^{* \star *}$ & $-0.193^{\star * *}$ & $-0.547^{* * *}$ & $-0.916^{\star * *}$ \\
\hline & {$[-3.27]$} & {$[-2.38]$} & {$[-0.08]$} & [16.66] & [11.00] & [10.73] & {$[-14.11]$} & {$[-20.82]$} & {$[-17.00]$} \\
\hline $\mathrm{N}$ & 5887 & 5887 & 5887 & 5887 & 5887 & 5887 & 5887 & 5887 & 5887 \\
\hline
\end{tabular}

Table 7: Regression results of Model 1 by percentile Q25, Q50, Q75 t statistics in brackets * $p<0.1,{ }^{* *} p<0.05,{ }^{* *} p<0.01$

\begin{tabular}{|c|c|c|c|c|c|c|c|c|c|}
\hline & \multicolumn{3}{|l|}{ LV } & \multicolumn{3}{|l|}{ SDA } & \multicolumn{3}{|l|}{ LDA } \\
\hline & Q25 & Q50 & Q75 & Q25 & Q50 & Q75 & Q25 & Q50 & Q75 \\
\hline \multirow[t]{2}{*}{ VCF } & $-0.445^{\star * *}$ & $-0.332^{\star \star *}$ & $-0.298^{* * *}$ & $-0.195^{\star \star *}$ & $-0.267^{\star * \star}$ & $-0.165^{\star \star}$ & $-0.0279^{*}$ & -0.0449 & 0.0223 \\
\hline & {$[-6.73]$} & {$[-4.76]$} & {$[-4.83]$} & {$[-4.29]$} & {$[-3.83]$} & {$[-2.20]$} & {$[-1.78]$} & {$[-1.48]$} & {$[0.36]$} \\
\hline \multirow[t]{2}{*}{ VCF_COVID } & $0.448^{\star * *}$ & $0.285^{\star \star \star}$ & $0.204^{\star \star \star}$ & $0.171^{\star * \star}$ & $0.250^{\star \star * *}$ & 0.091 & 0.0278 & 0.0383 & -0.0442 \\
\hline & [5.87] & [3.54] & [2.86] & [3.26] & [3.12] & {$[1.05]$} & [1.53] & [1.09] & {$[-0.61]$} \\
\hline \multirow[t]{2}{*}{ SIZE } & $0.0284^{* * *}$ & $0.0300^{* * *}$ & $0.0287^{* * *}$ & $-0.00694^{* * *}$ & -0.00249 & 0.000118 & $0.00734^{* * *}$ & $0.0214^{* \star *}$ & $0.0374^{* * *}$ \\
\hline & [13.71] & [13.75] & {$[14.86]$} & {$[-4.89]$} & {$[-1.14]$} & {$[0.05]$} & [14.96] & [22.46] & [19.05] \\
\hline \multirow[t]{2}{*}{ TANG } & $-0.146^{\star * *}$ & $-0.113^{* * *}$ & $-0.121^{* * *}$ & $-0.291^{* * *}$ & $-0.374^{* * *}$ & $-0.429^{* * *}$ & $0.0634^{* * *}$ & $0.209^{* * *}$ & $0.287^{* * *}$ \\
\hline & {$[-9.17]$} & {$[-6.73]$} & {$[-8.10]$} & {$[-26.63]$} & {$[-22.27]$} & {$[-23.66]$} & {$[16.77]$} & [28.49] & [18.99] \\
\hline \multirow[t]{2}{*}{ ROA } & $-0.515^{\star * *}$ & $-1.000^{* * *}$ & $-1.263^{\star * *}$ & $-0.0588^{\star *}$ & $-0.456^{\star \star \star *}$ & $-0.900^{* * *}$ & $-0.0460^{* * *}$ & $-0.130^{* * *}$ & $-0.294^{\star * *}$ \\
\hline & {$[-13.77]$} & {$[-25.35]$} & {$[-36.16]$} & {$[-2.29]$} & {$[-11.59]$} & {$[-21.14]$} & {$[-5.18]$} & {$[-7.57]$} & {$[-8.29]$} \\
\hline \multirow[t]{2}{*}{ MB } & $-3.73 \mathrm{E}-05$ & $0.0105^{* * *}$ & $0.0203^{* * *}$ & $0.00636^{* * *}$ & $0.0176^{* * *}$ & $0.0255^{* * *}$ & $-0.00160^{* *}$ & $-0.00277^{* *}$ & 0.001 \\
\hline & {$[-0.01]$} & [3.61] & {$[7.86]$} & [3.35] & {$[6.06]$} & [8.10] & {$[-2.45]$} & {$[-2.18]$} & [0.38] \\
\hline \multirow[t]{2}{*}{ LIQ } & $-0.0673^{* * *}$ & $-0.0486^{* * *}$ & $-0.0297^{* * *}$ & $-0.0578^{* * *}$ & $-0.0572^{* * *}$ & $-0.0352^{* * *}$ & -0.00025 & -0.000154 & 0.000392 \\
\hline & {$[-99.15]$} & {$[-68.00]$} & {$[-46.81]$} & {$[-124.20]$} & {$[-80.19]$} & {$[-45.65]$} & {$[-1.56]$} & {$[-0.49]$} & [0.61] \\
\hline \multirow[t]{2}{*}{ cons } & $-0.169^{* * *}$ & $-0.132^{\star *}$ & -0.00827 & $0.658^{* \star *}$ & $0.669^{* \star *}$ & $0.713^{* \star *}$ & $-0.191^{* \star *}$ & $-0.549^{* * *}$ & $-0.917^{* * *}$ \\
\hline & {$[-2.99]$} & {$[-2.20]$} & {$[-0.16]$} & [16.94] & [11.22] & [11.06] & {$[-14.22]$} & {$[-21.09]$} & {$[-17.07]$} \\
\hline$N$ & 5887 & 5887 & 5887 & 5887 & 5887 & 5887 & 5887 & 5887 & 5887 \\
\hline
\end{tabular}

Table 8: Results of regression model 2 on the impacts of COVID by percentile Q25, Q50, Q75 t statistics in brackets ${ }^{*} p<0.1,{ }^{* *} p<0.05,{ }^{* * *} p<0.01$ 


\section{Conclusion}

Optimal capital structure is always one of the goals that managers aim for. There are many factors that affect the capital structure decision of enterprises. In this paper, we study the impact of cash flow volatility on debt structure in Vietnamese enterprises. Using a panel dataset extracted from the balance sheets and income statements of joint stock enterprises in Vietnam for the period 2009-2020, we find evidence to support the studies of Frank \& Goyal (2009) and the pecking order theory as follows:

Firstly, we find a negative correlation between cash flow volatility and the debt structure (financial leverage, short-term debt ratio, and long-term debt ratio). Enterprises with high cash flow volatility tend to reduce debt because this exposes them to high business risk, increase the likelihood of financial distress, and lower the present value of the tax shield (Jensen, 1986). Therefore, these enterprises often reduce debt to reduce the financial risk affecting the overall business risk. In addition, other factors such as market to book value and firm size are positively correlated with debt structure, while tangible assets, liquidity, and profitability are negatively correlated to debt structure. In particular, when considering the impact of the COVID pandemic, the interaction variable VCF-COVID has a positive relationship with the debt structure of enterprises.

Previous studies have focused on the impact of cash flow volatility and capital structure without considering the impact of the COVID pandemic. In this study, we focus on examining the difference in the relationship between cash flow volatility and debt structure in the context of the COVID pandemic with unexpected results, and on the positive relationship of the interaction variable VCF COVID impact on debt structure (financial leverage, short-term debt ratio and long-term debt ratio).

Finally, we conduct quantile regression based on the debt structure of each enterprises at three percentiles (Q25\%, Q50\%, Q75\%). Through that, we detect a negative and statistically significant relationship between cash flow volatility and corporate debt structure. At the low stages of debt structure, the impact of cash flow volatility on debt structure is higher. This result shows that listed enterprises in Vietnam in the period of good performance have enough resources to face cash flow risks, so there is no need to use debt. On the contrary, in the period of poor performance, enterprises are passive with capital for business activities, so they need to increase additional capital from outside to support.

\section{Reference}

[1] Baker, S. R., Bloom, N., Davis, S. J., Kost, K., Sammon, M., \& Viratyosin, T. (2020). The unprecedented stock market reaction to COVID-19. COVID Economics: Vetted and RealTime Papers, 1(3).

[2] BATES, T. W., KAHLE, K. M., \& STULZ, R. M. (2009). Why Do U.S. Firms Hold So Much More Cash than They Used To? The Journal of Finance, 64(5), 1985-2021. doi:10.1111/j.1540-6261.2009.01492.x

[3] Chen, J. J. (2004). Determinants of capital structure of Chinese-listed companies. Journal of Business Research, 57(12), 1341-1351. doi:10.1016/s0148-2963(03)00070-5
[4] Dang Ngoc, H., Vu Thi Thuy, V., \& Le Van, C. (2021). Covid 19 pandemic and Abnormal Stock Returns of listed companies in Vietnam. Cogent Business \& Management, 8(1), 1941587. doi:10.1080/23311975.2021.1941587

[5] [5] Dang, N. H., \& Tran, M. D. (2020). Impact of financial leverage on accounting conservatism application: the case of Vietnam. CUSTOS E AGRONEGOCIO ON LINE, 16(3), 137158.

[6] [6] Denis, D. J., \& McKeon, S. B. (2018). Persistent operating losses and corporate financial policies. Available at SSRN 2881584

[7] Frank, M. Z., \& Goyal, V. K. (2009). Capital Structure Decisions: Which Factors Are Reliably Important? Financial Management, 38(1), 1-37. doi:10.1111/j.1755053x.2009.01026.x

[8] [8] Ha, T. V., Dang, N. H., Tran, M. D., Van Vu, T. T., \& Trung, Q. (2019). Determinants Influencing Financial Performance of Listed Firms: Quantile Regression Approach. Asian Economic and Financial Review, 9(1), 78-90. doi: DOI: 10.18488/journal.aefr.2019.91.78.90

[9] Harris, C., \& Roark, S. (2019). Cash flow risk and capital structure decisions. Finance Research Letters, 29, 393-397. doi:10.1016/j.frl.2018.09.005

[10] Huang, R., \& Ritter, J. R. (2020). Corporate Cash Shortfalls and Financing Decisions. The Review of Financial Studies, 34(4), 1789-1833. doi:10.1093/rfs/hhaa099

[11] Jensen, M. C. (1986). Agency costs of free cash flow, corporate finance, and takeovers. The American economic review, 76(2), 323-329.

[12] Keefe, M. O., \& Yaghoubi, M. (2016). The influence of cash flow volatility on capital structure and the use of debt of different maturities. Journal of Corporate Finance, 38, 18-36. doi:10.1016/j.jcorpfin.2016.03.001

[13] Memon, Z. A., Chen, Y., Tauni, M. Z., \& Ali, H. (2018). The impact of cash flow volatility on firm leverage and debt maturity structure: evidence from China. China Finance Review International.

[14] Myers, S. C., \& Majluf, N. S. (1984). Corporate financing and investment decisions when firms have information that investors do not have. Journal of Financial Economics, 13(2), 187-221. doi:10.1016/0304-405x(84)90023-0

[15] Phuong, N. T. T., Hung, D. N., Van, V. T. T., \& Xuan, N. T. (2020). EFFECT OF DEBT STRUCTURE ON EARNINGS QUALITY OF ENERGY BUSINESSES IN VIETNAM. International Journal of Energy Economics and Policy, 10(3), 396-401. doi:10.32479/ijeep.9110

[16] Van Khanh, V. T., \& Hung, D. N. (2020). Impact of Earnings Quality on the Debt Maturity: The Case of Vietnam. Asian Economic and Financial Review, 10(1), 1-12.

[17] Wald, J. K. (1999). HOW FIRM CHARACTERISTICS AFFECT CAPITAL STRUCTURE: AN INTERNATIONAL COMPARISON. Journal of Financial Research, 22(2), 161187. doi:10.1111/j.1475-6803.1999.tb00721.x

[18] Hoang, T. V. H., Dang, N. H., Tran, M. D., Vu, T. T. V., \& Pham, Q. T. (2019). Determinants Influencing Financial Performance of Listed Firms: Quantile Regression Approach. Asian Economic and Financial Review, 9(1), 78-90. doi:10.18488/journal.aefr.2019.91.78.90 